\title{
Variability, Heritability and Genetic Advance for Cane Yield and its Contributing Traits in Sugarcane Clones under Waterlogged Condition
}

\author{
Rupesh Kumar Agrawal and Balwant Kumar*
}

\author{
Plant Breeding and Genetics, S.R.I., Dr. Rajendra Prasad Central Agricultural University, \\ Pusa Bihar, 848 125, India \\ *Corresponding author
}

\begin{tabular}{|c|c|}
\hline & A B S T R A C T \\
\hline & \multirow{6}{*}{$\begin{array}{l}\text { In a field experiment sixteen sugarcane clones including two checks were planted with } \\
\text { three replications in RBD at Paddy Block, RAU, Pusa, Samastipur, Bihar during } 2012-13 \\
\text { under low land area where its grand growth phase coincides with water-stagnation depth } \\
40-45 \mathrm{~cm} \text { for three months to study the variability, heritability and genetic advance of } \\
\text { Sugarcane clones under water-logging condition for the traits viz, Germination } \\
\text { Percentage at } 45 \text { days, Number of Shoots at } 120 \text { days, Plant Height at } 150,240 \text { and } 360 \\
\text { days, Cane diameter, NMC, Single Cane weight, Red Rot Score, Brix at } 10,11 \text { and } 12 \\
\text { month, Pol at } 10,11 \text { and } 12 \text { month, Purity at } 10,11 \text { and } 12 \text { month, CCS Per cent at harvest } \\
\text { and Cane yield. Highly significant variation was observed for all traits except purity at } 10 \\
\text { and } 11 \text { month stage and CCS percent at harvest. High heritability coupled with high } \\
\text { genetic advance as per cent of mean found for traits viz. number of shoots at } 120 \text { days, } \\
\text { plant height at } 240 \text { and } 360 \text { days and single cane weight which will in favor of direct } \\
\text { selection. Highest GCV and PCV were recorded for number of shoots at } 120 \text { days } \\
\text { followed by plant height at } 240 \text { days and plant height at } 360 \text { days, indicating the } \\
\text { importance of these traits to evaluate for water-logging tolerance. Comparatively the } \\
\text { maximum phenotypic and genotypic variance were exhibited by the traits viz. plant height } \\
\text { at } 360 \text { and } 240 \text { days, number of shoots at } 120 \text { days, plant height at } 150 \text { days, number of } \\
\text { millable canes and cane yield (t/ ha).Number of shoots at } 120 \text { days, plant height at } 240 \\
\text { days, plant height at } 360 \text { days, and single cane weight showed high heritability coupled } \\
\text { with high genetic advance. Hence, direct selection can be done through these characters for } \\
\text { future improvement of varieties. }\end{array}$} \\
\hline Keywords & \\
\hline $\begin{array}{l}\text { Sugarcane, } \\
\text { Water logging, } \\
\text { Variability, PCV, } \\
\text { GCV, Heritability, } \\
\text { Genetic advance. }\end{array}$ & \\
\hline Article Info & \\
\hline $\begin{array}{l}\text { Accepted: } \\
\text { 23 May } 2017 \\
\text { Available Online: } \\
\text { 10 June } 2017\end{array}$ & \\
\hline & \\
\hline
\end{tabular}

\section{Introduction}

Varieties differ in degree of tolerance to water-logging based on certain inherent genetic characteristics, age of the crops and other growing conditions. A large difference in varietal response to water-logging in sugarcane has been reported. The varieties which are doing comparatively well under water-logging situation are BO91, BO110 and BO147, therefore only these three varieties cover more than $40 \%$ sugarcane cultivated area in Bihar. The recovery of sugarcane in Bihar has been found lower than the other states of India since last 3 decade. Sugar industries in Bihar is facing several challenges and most of the sugarcane industries are closed since last three decade due to various reason, among them major is 35-40 per cent of sugarcane growing area (presently total area 
under sugarcane in the state is 3.00 lakh ha) in Bihar is prone to water-logging situation. Low productivity of sugarcane in Bihar has been recorded since last fifty year (approximately 30-50 t/ha.) due to lack of stable high yielder water logging tolerant variety. It is fact that in water-logged areas, cane yield generally declined by $15-20$ per cent. If the waterlogging is in the early stage of crop growth it affects the germination, tillering and cane growth, which may result in crop failure. Generally, the water-logging coincides with the grand growth phase and may extend up to maturity of the crop and hence, the early planted crop suffers less. For the clonal differences in the response of severe waterlogging was studied and found that under artificially created conditions of prolonged water-logging Saccharum spp.

Hybrid Complex clones were highly susceptible and did not survive whereas the clones of Saccharum barberi, Saccharum sinense, Saccharum sclerostachya and Saccharum erianthus survived. Several clones of Saccharum spontaneum, Saccharum robustum and Saccharum narenga were water-logging tolerant. In the breeding of sugarcane, it has been a general practice to cross the different species with the noble cane, $S$. officinarum, to combine the high sugar yield of the officinarum clones with hardiness and disease resistance of the other species, a procedure called nobilization. Todays hybrid complexes i.e. Saccharum spp. clones with water-logging tolerant genes can do well under water-logging condition which requires systematic study on their comparative tolerance. Although the use of high yielding varieties coupled with moderate to high sucrose and also having water-logging tolerance capacity contribute substantially in sugarcane production and productivity but still there is need to screen sugarcane varieties tolerant to water-logging condition for its better adaptability and to overcome the problem of water-logging areas under sugarcane cultivation which will enhance the productivity as well as recovery of this crop. Therefore present investigation was formulate to study the variability, heritability and genetic advance of Sugarcane clones under waterlogging condition for the productive traits which will be helpful for the researches as well as farmers of sugarcane cultivation under such type of water-logging areas of Bihar.

\section{Materials and Methods}

The present experiment was conducted in the fields located at Paddy Block, RAU, Pusa, Samastipur, Bihar during 2012-2013 with sixteen promising sugarcane clones viz., BO153, BO141, CoSe96436, CoX07067, CoP081, CoP091, CoP02061, CoP111, CoP04181, BO155, BO154, BO146, CoP092 (CoP 9437), Colk94184 including two checks namely BO91 and BO147 under water-logged condition and a minimum of 40-45 cm depth of water is maintained during July-October. All the sixteen clones were grown under field condition in Randomized Block Design (RBD) with three replications follow all agronomical package and practices. In each replication each variety was grown in a plot of 6 rows of 6 meters length each with a spacing of 0.90 meter between rows and plot size is $32.4 \mathrm{~m}^{2}$.

Observations were record by selecting five random plants per genotype per replication for cane yield and yield attributing characters viz, Germination Percentage at 45 days, Number of Shoots at 120 days, Plant Height at 150, 240 and 360 days, Cane diameter, NMC, Single Cane weight, Red Rot Score, Brix at 10,11 and 12 month, Pol at 10, 11 and 12 month, Purity at 10, 11 and 12 month, CCS Per cent at harvest and Cane yield. Red rot score (0-9 scale) was observed after splitting of five randomly selected plants of each genotype per replication. 


\section{Statistical analysis}

Estimation of variance components Genotypic and phenotypic components of variance were estimated with the help of following formulae

Genotypic Variance $\left(\sigma_{\mathrm{g}}{ }^{2}\right)=($ vMSS - EMSS $)$ $\mathrm{x} \mathbf{C F}$

Phenotypic variance $\left(\sigma_{\mathrm{p}}{ }^{2}\right)=\sigma_{\mathrm{g}}{ }^{2}+$ EMS

\section{Coefficient of variability}

Both genotypic and phenotypic coefficient of variability were computed for each character as per method suggested by Burton and De Vane (1953)

Genotypic Coefficient of Variation $(\mathrm{GCV})=$ genotypic standard deviation $\left(\sigma_{\mathrm{g}}\right)$ divided by grand mean of the character $\mathrm{x} 100$

Phenotypic Coefficient of Variation (PCV) $=$ Phenotypic standard deviation $\left(\sigma_{\mathrm{p}}\right)$ divided by grand mean of the character $\mathrm{x} 100$

\section{Heritability $\left(h^{2}\right)$}

It was estimated in broad sense by using following formula as suggested by Lush (1940).

$\mathbf{h}^{2}=$ Genotypic variances $\left(\sigma_{\mathrm{g}}{ }^{2}\right)$ divided by Phenotypic variances $\left(\sigma_{\mathrm{p}}{ }^{2}\right) \times 100$

Genetic advance (GA) for each character was computed by adopting the formulae given by Johnson et al., (1955).

$\mathrm{GA}=\mathrm{h}^{2} \cdot \mathrm{K} \cdot \sigma_{\mathrm{p}}$

Where,

$\mathrm{h}^{2}=$ Heritability of the character.

$\mathrm{K}=$ Selection differential which is equal to 2.06 at 5 percent intensity of selection (Lush, 1949). $\sigma_{\mathrm{p}}=$ Phenotypic standard deviation of the character

Genetic advance as per cent of mean (GAM)

GAM $(\%)=$ Genetic advance (GA) divided by General mean of population $(\mathrm{Gm}) \times 100$

The estimates of variability parameters that are coefficient of variation at genotypic (GCV), phenotypic (PCV), environmental level (ECV), heritability (\%) and genetic advance as percentage of mean. In general the estimated values of PCV were higher than GCV for all the characters studied indicating role of environment on the performance of clones. GCV and PCV values were categorized as low (0-10\%), moderate (10$20 \%$ ) and high (20 and above) as indicated by Sivasubramanian and Menon (1973). The heritability was categorized as low (0-30\%), moderate $(30-60 \%)$ and high (60 and above) as given by Robinson et al., (1949). Genetic advance as per cent mean was categorized as low (0-10\%), moderate (10-20\%) and high (20 and above) as given by Johnson et al., (1955).

\section{Results and Discussion}

Genetic variability is one of the important consideration in any crop improvement which is needed to study in detail. Variability is measure by estimation of genotypic and phenotypic variance $\left(\sigma^{2} \mathrm{~g}\right.$ and $\left.\sigma^{2} \mathrm{p}\right)$, genotypic and phenotypic coefficient of variation (GCV and PCV), heritability, genetic advance and genetic advance as per cent of mean. These parameters help in selection for improvement of desired characters. Environment plays an important role in the expression of phenotype. The phenotypic variability which is observable includes both genotypic (heritable) and environmental variation (non-heritable). Hence, variability can be observed through biometric parameters like GCV, heritability 
(broad sense) and genetic advance. The analysis of variance (Table 1) revealed highly significant variation among the varieties for all the 19 traits studied except purity at 10 month stage, purity at 11 month stage and CCS per cent at harvest under water-logging condition. This indicated that there was presence of sufficient variability in the material studied under water-logging condition because of the fact that these clones were derived from parents having different 'backgrounds' geographical one. In other words further analysis of water-logging tolerance is meaningful as indicated by significant mean sum of squares under water-logging condition i.e., stress condition. Many earlier workers, Tyagi and Singh (1998), Kadian et al., (1997), Kumar and Singh (1999), Gupta and Chatterjee (2002), Thippeswamy et al., (2001), Puneet et al., (2001), Hapase and Repale (2004), Doule and Balasundaram (2003), Singh et al., (2010) and Nair and Somarajan (1986) reported high variability for different traits in sugarcane. Thus, it is implied that there was reasonably sufficient variability in material used for their study, which provides ample scope for selecting superior and desire clone by the plant breeder for further improvement. The phenotypic variances for all the traits under studied were higher than the genotypic variances (Kadian et al., (1997). This may be due to the nongenetic factor which played an important role in the manifestation of these characters. A perusal of table 3 revealed that phenotypic coefficient of variation was higher than the genotypic coefficient of variation for all the traits under investigation. The narrow difference between PCV and GCV were recorded for most of the traits. High phenotypic coefficient of variability was recorded for number of shoots per hectare at 120 days after planting (20.91) followed by plant height at 240 days after planting (20.09), plant height at 360 days after planting (17.97), number of millable canes (15.72), cane yield
(15.06), Almost same trend has been recorded for genotypic coefficient of variability with maximum value for number of shoots per hectare at 120 days after planting (18.29), followed by plant height at 240 days after planting (17.86), plant height at 360 days after planting (15.48). The characters having moderate phenotypic coefficient of variability were CCS per cent at harvest (14.69), single cane weight (13.97), plant height at 150 days (13.90), germination percent at 45 days (12.56), cane diameter at harvest (12.18), pol at 10 month stage (11.87), brix at 10 month stage (11.69), pol at 12 month stage (10.78) and pol at 11 month stage (10.30). Moderate genotypic coefficient of variability were exhibited by the characters namely, single cane weight (13.77), number of millable canes (12.00), cane yield (10.77) and plant height at 150 days (10.40). Low phenotypic coefficient of variability was recorded for brix at 11 month stage (9.19), brix at 12 month stage (8.92), purity at 12 month stage (6.03), purity at 11 month stage (4.96) and purity at 10 month stage (4.38). Similarly, low genotypic coefficient of variability were shown by the characters namely, pol at 10 month stage (9.01), brix at 10 month stage (8.79), cane diameter at harvest (7.58), pol at 12 month stage (7.48), CCS per cent at harvest (7.28), pol at 11 month stage (6.76), germination per cent at 45 days (6.75), brix at 11 month stage (5.05), brix at 12 month stage (4.83), purity at 12 month stage (3.58), purity at 10 month stage (2.01) and purity at 11 month stage (0.62).Wide ranges of variance (phenotypic and genotypic) were observed in the experimental material for all the characters under investigation. The maximum phenotypic and genotypic variance exhibited by the traits, plant height at 360 days, plant height at 240 days, number of shoots at 120 days, number of millable canes, cane yield, and germination percentage at 45 days under water-logging condition. These findings were in accordance with the result of Kumar and Singh (1999), 
Gupta and Chatterjee (2002), Thippeswamy et al., (2001), who also observed high variance for yield and yield component traits among sugarcane genotypes. The assessment of heritable and non-heritable components in the total variability observed is indispensable in adopting suitable breeding procedure. The heritable portion of the overall observed variation can be ascertained by studying the components of variation such as GCV, PCV, heritability and genetic advance as per cent of mean.

The genotypic and phenotypic coefficient of variation (Table 3 ) found to be high for traits viz. number of shoots per hectare at 120 days, followed by plant height at 240 days, plant height at 360 days, single cane weight and number of millable canes. These results are in agreement with Kumar and Singh (1999) for all the characters cited above. The results showed high GCV and PCV for number of shoots at 120 days, indicating the importance of this trait in evaluation of clones for waterlogging tolerance and selecting the varieties for water-logging tolerance. These findings were clearly indicated that selecting genotypes through the traits viz. number of shoots per hectare at 120 days, followed by plant height at 240 days, plant height at 360 days, single cane weight, and number of millable canes will be effective for water-logging tolerance. It is interesting to note that the differences between GCV and PCV values were minimum implying least influence of environment and additive gene effects indicating genotypes can be improved and selected for these characters under stress condition for improvement of water-logging tolerance. Heritability is a measure of the extent of phenotypic variation caused by the action of genes. It is a good index of the transmission of characters from parents to their offspring (Falconer, 1989). For making effective improvement in the characters for which selection is practiced, heritability has been adopted by large number of workers as a reliable indicator. The estimates of heritability help plant breeder in selection of elite genotypes from diverse genetic population. The estimates of heritability are more advantageous when expressed in terms of genetic advance. Hanson (1963) stated that heritability and genetic advance are two complementary concepts. However it is not necessary that a character showing high heritability will also exhibit high genetic advance (Johnson et al., 1955a).The heritability in broad sense and genetic advance as per cent of mean was worked out for all the characters, have been presented in table 3 and their performance adjudged on the basis given by Robinson et al., (1949) for heritability and Johnson et al., (1955a) for genetic advance as per cent of mean.

\begin{tabular}{|l|l|l|}
\hline Category & $\begin{array}{l}\text { Heritability } \\
\text { (broad } \\
\text { sense) }\end{array}$ & $\begin{array}{l}\text { Genetic Advance as } \\
\text { per cent of mean }\end{array}$ \\
\hline $\begin{array}{l}\text { High } \\
\text { Moderate }\end{array}$ & $\begin{array}{l}>60 \% \\
30 \%-60 \% \\
\text { Low }\end{array}$ & $\begin{array}{l}>20 \% \\
10 \%-20 \% \\
<30 \%\end{array}$ \\
\hline
\end{tabular}

On the basis of this characterization it was clear from table 3 that maximum heritability (broad sense) was observed for single cane weight (97) followed by plant height at 240 days (79), number of shoots at 120 days (76) and plant height at 360 days (74). Moderate heritability (broad sense) was observed for the characters viz. pol at 10 month stage and number of millable canes (58) followed brix at 10 month stage (57), plant height at 150 days (56), cane yield (51), pol at 12 month stage (48), pol at 11 month stage (43), cane diameter at harvest (39), germination percent at 45 days (38), purity at 12 month stage (35) and brix at 11 month stage (30). Low heritability (broad sense) were observed for the characters brix at 12 month stage (29), CCS per cent at harvest (25), purity at 10 month stage (21) and purity at 11 month stage (20). 
Table.1 Analysis of variance for nineteen characters of sixteen sugarcane varieties under water-logging condition

\begin{tabular}{|c|c|c|c|c|}
\hline \multirow{2}{*}{$\begin{array}{l}\text { Sr. } \\
\text { No. }\end{array}$} & \multirow[t]{2}{*}{ Characters } & \multicolumn{3}{|c|}{ Mean sum of squares } \\
\hline & & $\begin{array}{c}\text { Replications } \\
\text { n (d.f.=2) }\end{array}$ & $\begin{array}{c}\text { Treatments } \\
(\text { d.f. }=15)\end{array}$ & $\begin{array}{c}\text { Error } \\
(\text { d.f.=30) }\end{array}$ \\
\hline 1 & Germination \% at 45 days After Planting & 0.02 & $31.19 * *$ & 10.94 \\
\hline 2 & Number of Shoots at 120 days ( 000/ha) & 15.32 & $1849.83 * *$ & 171.95 \\
\hline 3 & Plant Height at 150 days $(\mathrm{cm})$ & 10.96 & $1135.86^{* *}$ & 235.79 \\
\hline 4 & Plant Height at 240 days $(\mathrm{cm})$ & 15.59 & $4388.67 * *$ & 356.97 \\
\hline 5 & Brix at 10 Month Stage (\%) & 0.28 & $9.39 * *$ & 1.91 \\
\hline 6 & Pol at 10 Month Stage (\%) & 0.10 & $7.45^{* *}$ & 1.47 \\
\hline 7 & Purity at 10 Month Stage (\%) & 13.05 & 8.56 & 17.86 \\
\hline 8 & Brix at 11 Month Stage (\%) & 0.14 & $4.57 * *$ & 1.99 \\
\hline 9 & Pol at 11 Month Stage (\%) & 0.08 & $5.00 * *$ & 1.53 \\
\hline 10 & Purity at 11 Month Stage (\%) & 1.93 & 18.00 & 18.88 \\
\hline 11 & Brix at 12 Month Stage (\%) & 0.37 & $4.04 * *$ & 1.80 \\
\hline 12 & Pol at 12 Month Stage (\%) & 0.36 & $5.50 * *$ & 1.46 \\
\hline 13 & Purity at 12 Month Stage (\%) & 0.65 & $47.12 * *$ & 17.86 \\
\hline 14 & CCS Per cent at Harvest & 0.57 & 3.65 & 1.85 \\
\hline 15 & Plant Height at 360 days $(\mathrm{cm})$ & 24.14 & $4518.52 * *$ & 468.80 \\
\hline 16 & Cane Diameter at harvest $(\mathrm{cm})$ & 0.0009 & $0.17 * *$ & 0.06 \\
\hline 17 & Single Cane Weight (kg) & 0.0003 & $0.04 * *$ & 0.0003 \\
\hline 18 & Number of Millable Canes (000/ ha) & 4.98 & $574.26 * *$ & 110.60 \\
\hline 19 & Cane Yield (tonne/ ha) & 3.59 & $314.37 * *$ & 75.93 \\
\hline
\end{tabular}


Table.2 Mean, range and coefficient of variance for nineteen characters of sixteen sugarcane varieties under water-logging condition

\begin{tabular}{|c|c|c|c|c|c|c|}
\hline \multirow{2}{*}{$\begin{array}{l}\text { Sr. } \\
\text { No. }\end{array}$} & \multirow{2}{*}{ Characters } & \multirow{2}{*}{ Symbol } & \multirow{2}{*}{ Mean \pm SEM } & \multirow[t]{2}{*}{ C.V. } & \multicolumn{2}{|c|}{ Range } \\
\hline & & & & & Min & Max \\
\hline 1 & Germination \% at 45 Days After Planting & G\% & $33.49 \pm 1.85$ & 11.25 & 28.72 & 39.79 \\
\hline 2 & Number of Shoots at 120 days ( 000/ha) & S120 & $129.30 \pm 7.33$ & 5.06 & 101.66 & 180.16 \\
\hline 3 & Plant Height at 150 days $(\mathrm{cm})$ & PH150 & $166.57 \pm 8.58$ & 6.36 & 134.66 & 202.30 \\
\hline 4 & Plant Height at 240 days $(\mathrm{cm})$ & PH240 & $205.27 \pm 10.56$ & 5.56 & 157.00 & 301.33 \\
\hline 5 & Brix at 10 Month Stage (\%) & B\%10 & $17.96 \pm 0.77$ & 3.87 & 14.73 & 21.97 \\
\hline 6 & Pol at 10 Month Stage (\%) & P\%10 & $15.68 \pm 0.68$ & 4.65 & 12.54 & 18.60 \\
\hline 7 & Purity at 10 Month Stage (\%) & PU\%10 & $87.65 \pm 2.36$ & 2.11 & 85.25 & 91.77 \\
\hline 8 & Brix at 11 Month Stage (\%) & B\%11 & $18.36 \pm 0.79$ & 3.48 & 15.73 & 20.00 \\
\hline 9 & Pol at 11 Month Stage (\%) & P\%11 & $15.91 \pm 0.69$ & 3.76 & 13.14 & 17.75 \\
\hline 10 & Purity at 11 Month Stage (\%) & PU\%11 & $86.88 \pm 2.43$ & 2.77 & 81.54 & 89.69 \\
\hline 11 & Brix at 12 Month Stage (\%) & B\%12 & $17.88 \pm 0.75$ & 3.86 & 15.73 & 20.47 \\
\hline 12 & Pol at 12 Month Stage (\%) & P\%12 & $15.53 \pm 0.67$ & 4.99 & 13.31 & 17.97 \\
\hline 13 & Purity at 12 Month Stage (\%) & PU\%12 & $87.17 \pm 2.36$ & 2.94 & 82.64 & 93.87 \\
\hline 14 & CCS Per cent at Harvest & $\mathrm{CCS} \%$ & $10.65 \pm 0.76$ & 9.52 & 9.01 & 12.39 \\
\hline 15 & Plant Height at 360 days $(\mathrm{cm})$ & PH360 & $237.33 \pm 12.10$ & 3.44 & 185.53 & 327.37 \\
\hline 16 & Cane Diameter at harvest $(\mathrm{cm})$ & CD & $2.57 \pm 0.14$ & 4.17 & 2.16 & 2.92 \\
\hline 17 & Single Cane Weight (kg) & SCW & $0.81 \pm 0.01$ & 7.09 & 0.59 & 0.98 \\
\hline 18 & Number of Millable Canes (000/ ha) & NMC & $103.56 \pm 5.88$ & 9.16 & 83.12 & 130.43 \\
\hline 19 & Cane Yield (tonne/ ha) & $\mathbf{C Y}$ & $82.78 \pm 4.87$ & 7.24 & 62.81 & 97.08 \\
\hline
\end{tabular}


Table.3 Genotypic variance $(\sigma 2 \mathrm{~g})$, phenotypic variance $(\sigma 2 \mathrm{p})$, genotypic coefficient of variance $(\mathrm{GCV})$, phenotypic coefficient of variance (PCV), heritability broad sense (h2) and genetic advance as per cent of mean (GA) for 19 characters of 16 sugarcane clones under water-logging condition

\begin{tabular}{|c|c|c|c|c|c|c|c|}
\hline Sr. No. & Characters & $\sigma_{g}^{2}$ & $\sigma_{p}^{2}$ & GCV & PCV & $\begin{array}{c}\mathbf{h}^{2} \\
(\text { Broad sense }) \%\end{array}$ & GA as $\%$ of Mean \\
\hline 1 & $\begin{array}{l}\text { Germination } \% \text { at } 45 \text { Days After } \\
\text { Planting }\end{array}$ & 6.75 & 17.69 & 6.75 & 12.56 & 38 & 9.87 \\
\hline 2 & $\begin{array}{l}\text { Number of Shoots at } 120 \text { days ( } \\
\text { 000/ha) }\end{array}$ & 559.29 & 731.24 & 18.29 & 20.91 & 76 & 32.95 \\
\hline 3 & Plant Height at 150 days (cm) & 300.02 & 535.81 & 10.40 & 13.90 & 56 & 16.03 \\
\hline 4 & Plant Height at 240 days (cm) & 1343.90 & 1700.87 & 17.86 & 20.09 & 79 & 32.70 \\
\hline 5 & Brix at 10 Month Stage (\%) & 2.49 & 4.40 & 8.79 & 11.69 & 57 & 13.63 \\
\hline 6 & Pol at 10 Month Stage (\%) & 1.99 & 3.46 & 9.01 & 11.87 & 58 & 14.07 \\
\hline 7 & Purity at 10 Month Stage (\%) & 3.10 & 14.76 & 2.01 & 4.38 & 21 & 1.90 \\
\hline 8 & Brix at 11 Month Stage (\%) & 0.86 & 2.85 & 5.05 & 9.19 & 30 & 5.71 \\
\hline 9 & Pol at 11 Month Stage (\%) & 1.16 & 2.69 & 6.76 & 10.30 & 43 & 9.14 \\
\hline 10 & Purity at 11 Month Stage (\%) & 0.29 & 18.58 & 0.62 & 4.96 & 20 & 1.16 \\
\hline 11 & Brix at 12 Month Stage (\%) & 0.75 & 2.55 & 4.83 & 8.92 & 29 & 5.40 \\
\hline 12 & Pol at 12 Month Stage (\%) & 1.35 & 2.80 & 7.48 & 10.78 & 48 & 10.68 \\
\hline 14 & CCS Per cent at Harvest & 0.60 & 2.45 & 7.28 & 14.69 & 25 & 7.44 \\
\hline 15 & Plant Height at 360 days $(\mathrm{cm})$ & 1349.91 & 1818.70 & 15.48 & 17.97 & 74 & 27.47 \\
\hline 16 & Cane Diameter at harvest $(\mathrm{cm})$ & 0.04 & 0.10 & 7.58 & 12.18 & 39 & 12.45 \\
\hline 17 & Single Cane Weight (kg) & 0.01 & 0.01 & 13.77 & 13.97 & 97 & 27.98 \\
\hline 18 & Number of Millable canes $(000 /$ ha) & 154.55 & 265.16 & 12.00 & 15.72 & 58 & 18.88 \\
\hline 19 & Cane Yield (tonne/ ha) & 79.48 & 155.41 & 10.77 & 15.06 & 51 & 15.87 \\
\hline
\end{tabular}


A perusal of genetic advance as per cent of mean (Table 3) revealed that it ranges from 1.16 (purity at 11 month stage) to 32.95 (number of shoots at 120 days). The result showed that four attributes namely number of shoots per hectare at 120 days (32.95), plant height at 240 days (32.70), single cane weight (27.98) and plant height at 360 days (27.47) were exhibited high genetic advance as per cent of mean (>20\%). Although, the traits number of millable canes (18.88), plant height at 150 days (16.03), cane yield (15.87), pol at 10 month stage (14.07), brix at 10 month stage (13.63), cane diameter at harvest (12.45) and pol at 12 month stage (10.68) showed medium genetic advance as per cent of mean $(10 \%-20 \%)$. However, the traits germination percent at 45 days (9.87), pol at 11 month stage (9.14), CCS per cent at harvest (7.44), brix at 11 month stage (5.71), brix at 12 month stage (5.40), purity at 12 month stage (4.39), purity at 10 month stage (1.90) and purity $\%$ at 11 month stage (1.16) were exhibited low genetic advance as percent of mean $(<10 \%)$. Comparatively the maximum phenotypic and genotypic variance were exhibited by the traits viz. plant height at 360 and 240 days, number of shoots at 120 days, plant height at 150 days, number of millable canes and cane yield ( $\mathrm{t} / \mathrm{ha}$ ).Number of shoots at 120 days, plant height at 240 days, plant height at 360 days, and single cane weight showed high heritability coupled with high genetic advance. Hence, direct selection can be done through these characters for future improvement of varieties.

\section{References}

Ahmed, A. O. and Obeid, A. (2010). Genetic divergence among sugarcane genotypes (Saccharum spp.) for cane yield attributes and Quality determinants. African Journal of Agicultural Research. 5(16):2103-2107.

Bairwa, A.K., Ram, R., Neetu., Jeena, A. S.,
Singh and Singh, 2017. Estimation of the extent of variability for different morphological and juice quality characters among early generation sugarcane clones. Int.J.Curr.Microbiol.App.Sci. $\quad$ 6(2): 1272-1278.

Anshuman, S., P. K. Bhatnagar., Khan, A. Q. and Shrotria, P. K. (2002). Variability and heritability for cane yield, its components and quality characters in sugarcane (Saccharum spp complex). Indian. Sug. J., 53(4) : 717719.

Bhatnagar, P. K., A. Q. Khan, A. Singh and K. A. Khan (2003). Studies on genetic variability, heritability and genetic advance in plant and ratoon crops of sugarcane. Indian Sugar, 53(3) : 183185.

Bakshi, Ram (1994). Variability, heritability, genetic advance and character interrelationships in sugarcane under coastal conditions of Andhra Pradesh, India. Agric. Sci. Dig., Karnal. 14(1): 44-48.

Doule, R. B. and Balasundaram, N. (2003). Genetic variability in sugar yield and its components for selection of sugarcane. Journal of Maharashtra Agricultural Universities. 27(3): 326-327.

Ghosh, J. and Singh, J. R. P. (1996). Variability in early maturing clones of sugarcane (Saccharum spp.). Cooperative Sugar. 27(5): 341-344.

Gupta, R. K. and Chatterjee, A. (2002). Study on some genetic parameters and its implication in selection of sugarcane (Saccharum officinarum). Cooperative Sugar. 33(10): 823-826.

Falconer, D. S. (1989). Introduction to quantitative genetics. $3^{\text {rd }}$ edition Longman. New York

Hapase, R S. and Repale, J. M. (1999) Variability, correlation and path analysis in sugarcane. Proceedings of the 61st Annual Convention of the 
Sugar-Technologists' Association of India, New-Delhi, India, 7-9 September. a130-a141.

Hapase, R. S. and Repale, J. M. (2004). Variability studies of some quantitative and qualitative characters in sugarcane varieties.

Indian Sugar. 54(3): 205-210.

Hapse, R. S. and D. G. Hapse (1990). Genetic Variability Studies in Late Maturing Sugarcane Varieties. Bharathiya Sug., $15: 13-16$.

Hooda, M. S. and Singh, S. (1989). Variability, heritability and genetic advance for yield and its components in sugarcane. Indian J. Agric. Sci. 59(3): 171-172.

Ishaq, N. M., Echekwu, C. A., Olorunju, P. E., Gupta, U. S. and Misari, S. M. (1998). Variability and correlation studies in sugarcane. Agricultura Tropica et Subtropica. (31): 45-52.

Johnson, H. W., Robinson, H. F. and Comstock, R. E. (1955a). Estimates of genetic and environmental variability in soybeans. Agron. J. $47: 314-318$.

Kadian, S. P., Chander Kishor and Sabharwal, P. S. (1997). Genetic variability and heritability in sugarcane. Indian Sugar. 46(12): 973-975.

Kadian, S. P., Chander Kishor and Sabharwal, P. S. (1997). Variability, heritability and genetic advance for yield and yield contributing characters in sugarcane (Saccharum hybrid spp.). Agric. Sci. Digest. 17(1): 51-53. 59-63.

Krishna Kumar., Singh, P. K. and Singh, J. R. P. (2004). Genetic variability and character association in sub-tropical clones of sugarcane (Saccharum complex hybrid). Indian Sugar. 54(3): 189-198.

Kumar, R. and Singh, J. R. P. (1999). Variability in sugarcane under waterlogged condition. Journal of Applied Biology. 9(2): 140-142.
Mali, S. C., Patel, A. I., Patel, D. U. and Patel, C. L. (2009). Variability, correlation, path analysis and genetic divergence in sugarcane (Saccharum spp.). Research on Crops. 10(2): 343-350.

Nair, N. V. and Somarajan, K. G. (1986). Genetic variability and character association in sugar cane. Sugarcane. (5): 8-10.

Puneet Jain., Rishi Pal., Saini, M. L. and Lajpat Rai. (2001). Variability, heritability and genetic advance for yield attributes in sugarcane. Indian Sugar. 51(5): 321-324.

Ravishankar, C. R., Ramappa, H. K., Prakash, P., Gowda, S. N. S. and Shivakumar, N. (2004). Genetic variability and correlations in sugarcane (Saccharum spp.) germplasm for quantitative characters. Environment and Ecology. 22(Spl-3): 569-571.

Robinson, H.F., Constock, R. E. and Harvey P.H. (1949). Estimates of heritability and the degree of dominance in corn. Agron. J. 41: 353-59.

Singh, M. K., Pandey, S. S., Kumar, R. and Singh, A. K. (2010). Estimation of genetic variability, heritability and genetic advance in mid-late maturing clones of sugarcane. Environment and Ecology. 28(4): 2301-2305.

Srinivasan, K. V. and Bhat, N. R. (1961). Red rot of sugarcane criteria for grading resistance. J. Indian Bot. Society, 40 : 566-577.

Thangavelu, S. (2005). Measurement of cane height of sugarcane clones at various growth phase and its association with some growth factors and yield of cane and sugar. Indian Sugar. 55(7): 15-22

Thangavelu, S. and Rao, K. C. (2003). Juice purity as a tool in identifying high sucrose sugarcane clones and its associations with other traits. Indian Sugar. 53(9): 703-708.

Thippeswamy, S., Kajjidoni, S. T., Salimath, 
P. M., Goud, J. V. and Chetti, M. B. (2001). Variability, heritability and genetic advance for cane yield and its components in sugarcane. Karnataka J. Agric. Sci. 14(1): 30-34.

Tyagi, S. D. and Singh, D. N. (1998). Studies on genetic variability for stalk characters in sugarcane. Indian Sugar. 48(4): 259-262.

Verma, P. S., Shri Pal. and Karma, N. K. (1999). Genetic variability and correlation studies in sugarcane. Indian Sugar. 49(2): 125-128

\section{How to cite this article:}

Rupesh Kumar Agrawal and Balwant Kumar. 2017. Variability, Heritability and Genetic Advance for Cane Yield and its Contributing Traits in Sugarcane Clones under Waterlogged Condition. Int.J.Curr.Microbiol.App.Sci. 6(6): 1669-1679. doi: https://doi.org/10.20546/ijcmas.2017.606.195 